\title{
Rationalizing Optimal Timing for Adjuvant Hormone Therapy for Patients with Breast Cancer: Impact on Limited Resource Countries
}

\author{
Kamalendu Malaker ${ }^{1,2}$ \\ ${ }^{1}$ Oncology Department, Princess Margaret Hospital, Roseau, Dominica \\ ${ }^{2}$ Ross University, Portsmouth, Dominica \\ Email:kamal_malaker@hotmail.com
}

Received 9 April 2016; accepted 27 June 2016; published 30 June 2016

Copyright (C) 2016 by author and Scientific Research Publishing Inc.

This work is licensed under the Creative Commons Attribution International License (CC BY). http://creativecommons.org/licenses/by/4.0/

(c) (†) Open Access

\begin{abstract}
Modern day cancer chemotherapy is complex and involves multiple drugs given either sequentially or concurrently, as an adjuvant or neo-adjuvant. Besides the concentration of the drug, timing, duration and sequencing of individual drugs in combination with other similar agents play a vital role in the final therapeutic outcome. This study constitutes an exhaustive overview of current knowledge of timing and sequencing, specifically of Tamoxifen, based on tumor's hormone receptor status, as part of a comprehensive treatment plan. It has become apparent that inappropriate timing or sequencing can be detrimental. On the other hand, appropriate timing and sequencing of Tamoxifen, based on breast cancer cell-biology, pharmacokinetics and pharmacodynamics of drugs, the body's homeostatic response to drugs; surgery and radiation, yield huge benefit for locoregional control, long-term survival and reducing complications in patients with breast cancer. Conclusion: A rational plan for use of Tamoxifen has been recommended, based on this study; for optimal therapeutic benefit. It has also been suggested that in receptor "unknown cases", it is beneficial to prescribe Tamoxifen, since $\mathbf{7 5 \%}$ of breast cancers are likely to be estrogen receptor positive and side effects can be minimized with planned vigilance.
\end{abstract}

\section{Keywords}

Optimization, Tamoxifen, Breast Cancer, Limited Resource Countries

\section{Introduction}

Tamoxifen (estrogen receptor modulator) and Letrozole (an aromatase inhibitor) are used extensively for ER

How to cite this paper: Malaker, K. (2016) Rationalizing Optimal Timing for Adjuvant Hormone Therapy for Patients with Breast Cancer: Impact on Limited Resource Countries. International Journal of Clinical Medicine, 7, 419-432. 
and PR receptor positive, for both pre- and post-menopausal patients, with breast cancer. In an adjuvant setting, when Tamoxifen is used as part of treatment, the optimum timing of sequencing hormones with chemotherapy, radiotherapy and surgery has been frequently queried.

On the clinic floor, the appropriate time to start and stop hormones if prescribed and the ability to stop at any time, if at all, or until the regimen finishes, are often asked by both patients and nursing staff alike.

The majority of cancer treatments involve multiple chemotherapy agents and multiple treatment modalities. Due to variable interaction with hormones and other therapeutic agents, it is important to have a clear understanding of the optimum dosage, sequencing and timing of each agent and each modality. This is likely to have a profound impact on the final outcome.

Optimizing time and sequence of surgery, radiotherapy and chemotherapy in the management of breast cancer can improve therapeutic benefits [1]. The addition of hormones and anti-hormones to breast cancer treatment armamentarium has improved the total outcome significantly [2] [3].

Sequencing chemotherapy with radiation and surgery for patients with breast cancer has been well studied in classical investigative work by Abraham Recht [1] Adjuvant chemotherapy, adjuvant radiotherapy, preoperative chemotherapy/radiotherapy, radiotherapy sandwiched between cycles of chemotherapy, and neo-adjuvant chemotherapy all have been extensively studied by many investigators following Recht's historical publication.

Studies to establish optimal sequencing of hormones with chemotherapy, radiotherapy and surgery appear to have generated moderate interest for clinical trials, in spite of hormones' vital role in the management of breast cancer. There have been several experimental studies [4] [5] confirming that it is worth noting that the role of Tamoxifen and estrogen on cell cycle and cell cycle dependent agents used for breast cancer may impact adversely or advantageously.

In 1981, it was proposed that adjuvant hormone therapy should be deferred during the course of chemotherapy. The simple assumption that Tamoxifen, being an estrogen receptor blocking agent, was likely to interfere with the dynamics of cycling cells, delay progression from G0 to G1 and increase in the proportion of G0/G1 phase, at the same time reducing the proportion of "S" phase. This dual effect reduces effectiveness of cell cycle dependent chemotherapy [6]. In fact, adjuvant estrogen might enhance the cell cycle and increase the proportion of "S" phase, making chemotherapy more effective [7].

The proposal at that point failed to raise intellectual curiosity. Recent rediscovery of the original proposal delighted the authors that the hypothesis is alive, being accepted (through the persistence of other investigators) and is practiced universally.

This study attempts to rationalize the importance of optimal sequencing of hormones, i.e., Tamoxifen, etc., with other primary treatment modalities for breast cancer.

\section{Role of Estrogen on Cell Cycle Regulation and Tumor Growth}

Estrogen increases the proportion of "S" and "G2-M" phases in cycling estrogen receptor positive and negative breast cancer cell lines. The effect of platelet derived factors that initiate cell cycles crossing over from one phase to the next is influenced by estrogen. The epidermal growth factor and insulin-like growth factor stimulate cycling cells to progress from G0/G1 phase to "S" phase, which is also influenced by estrogen [8]. Thus, estrogen itself, by promoting cell cycle "S" phase accumulation, promotes tumor growth, invasion and metastasis.

\section{Effect of Tamoxifen on the Cell Cycle}

Tamoxifen, by contrast, is an estrogen-blocking agent. It exerts its anti-tumor activity by competing for and binding to cytoplasmic estrogen receptor proteins in the tumor. The drug acts as an estrogen antagonist [9]. Thus it promotes accumulation of G0/G1 phases of cycling breast cancer cells and impairs crossing over and progression forward to "S" phase. Tamoxifen retards the cell cycle by impairing the effect of growth factors on cells and reducing the effect of cell cycle dependent anti-cancer agents, i.e., cytotoxic drugs and ionizing radiation. However, Tamoxifen is also known to arrest G2/M phase [10]. G2/M phase is sensitive to radiation and certain microtubule-disrupting chemotherapy agents, i.e., Vincristine, Taxol, etc.

\section{Cycling Cell Dependent Chemotherapy Agents}

Cytotoxic cancer chemotherapeutic agents are essentially “cell cycle dependent” for their oncotoxic activity, ir- 
respective of cell cycle phase dependence or independence. Chemotherapy works by killing actively growing and dividing cells. There are more dividing and metabolically active cells in cancerous tissue than its normal counterpart, which is responsible for the drug's therapeutic advantage.

Both genetic and epigenetic mechanisms are engaged in transformation of normal cells to cancer cells, affecting the orderly expression of cell cycle regulatory proteins. Transformed malignant cells have deregulated CDK activity, offering the malignant cells the advantages of faster cell cycle and growth [11]. Hence, cycling cells in "S" and "M" phases are important for chemotherapy to be effective as opposed to resting phase of G0 and G1 phase.

Any condition or agents that accumulate cells in G0 phase or arrests progression from G0 to G1 to "S" phase would inhibit the effectiveness of cancer chemotherapy. Tamoxifen does just that. Tamoxifen, by retaining more cells in G0/G1 and G2 phases of the cell cycle, induces relative resistance to the majority of cancer chemotherapy agents, compromising their therapeutic advantage [12].

\section{Effect of Tamoxifen on Cycle Dependent Chemotherapy Drug Activity}

From the above narrative, one can clearly deduce that Tamoxifen and other hormone receptor regulators will have a detrimental and deleterious effect on the cytotoxic function of cancer chemotherapy drugs, eventually compromising their therapeutic benefits.

On the other hand, it has been postulated that estrogen may enhance the cytotoxicity of chemotherapy drugs used for breast cancer treatment by acting as an additive or sensitizing factor by increasing percentage of " $\mathrm{S}$ " phase of cycling cells [13].

\section{Concurrent or Sequential Tamoxifen with Chemotherapy-Clinical Studies (Table 1)}

The debate of concurrent or sequential use of hormones, especially Tamoxifen and chemotherapy, is reasonably settled. Clinical studies (Table 1) indicated that due to the cytostatic effect of Tamoxifen and other associated hormones used for cancer treatment, it is better given sequentially and not concurrently. As discussed above, concurrent usage of hormones is likely to compromise the cytotoxic effect of cancer chemotherapy, which is dependent on cycling cells especially on the "S" phase component.

Table 1. Chemotherapy—-hormone therapy; concomitant or sequential clinical studies.

\begin{tabular}{|c|c|c|}
\hline Author & Type of study & Conclusion \\
\hline Gradishar W, et al. (2006) [2] & $\begin{array}{l}\text { Analysis: multiple } \\
\text { prospective study }\end{array}$ & Sequential recommended: Tamoxifen \& Anastozole Combo is better \\
\hline Baum M, 1988 [3] & $\begin{array}{l}\text { Global multi-centric } \\
\text { prospective }\end{array}$ & $\begin{array}{l}\text { Adjuvant Tamoxifen on pre \& postmenopausal Advantage: No } \\
\text { comment on CON V SEQ }\end{array}$ \\
\hline Pritchard KI, 2008 [14] & Review \& Reflective & Hormone with chemo; CON V SEQ: yet a matter of debate \\
\hline Albain K, et al. 2002 [15] & $\begin{array}{l}\text { Prospective \& } \\
\text { Randomized }\end{array}$ & Should be "sequenced not concurrent" \\
\hline Pico C, et al. 2004 [16] & $\begin{array}{l}\text { Trend in favor of } \\
\text { sequential }\end{array}$ & Trend in favor of sequential \\
\hline Bedgonetti D, et al. 2011 [17] & $\begin{array}{l}\text { Prospective \& } \\
\text { Randomized }\end{array}$ & No diff: CON V SEQ: Poor statistical power \\
\hline Del Mastro L, et al. 2008 [18] & $\begin{array}{l}\text { Prospective \& } \\
\text { Randomized }\end{array}$ & $\begin{array}{l}\text { OS, DFS, Toxicity score: CON V SEQ = no difference Decreasing } \\
\text { hazard of death-SEQ-group }\end{array}$ \\
\hline Sideras K, 2010 [19] & $\begin{array}{l}\text { Prospective \& } \\
\text { Randomized }\end{array}$ & Post-menopausal node + , Oe $+->$ SEQ more effective \\
\hline $\begin{array}{c}\text { Early Breast Cancer Trialists } \\
\text { Collaborative Group (EBCTCG) } \\
2005 \text { [20] }\end{array}$ & $\begin{array}{c}\text { Prospective \& } \\
\text { Randomized } \\
145,000 \text { pt-15 yr FU }\end{array}$ & $\begin{array}{l}\text { CT + SEQ Tam significantly better than CT + No Tam CON V } \\
\text { SEQ - not recorded }\end{array}$ \\
\hline
\end{tabular}




\section{Effect of Tamoxifen on Cycle Dependent Chemotherapy Drug Activity}

Ionizing radiation used for radiotherapy is essentially independent of cell cycle or cycling cells. It damages cells indiscriminately, irrespective of their malignant, benign or normal physiological status. Ionizing radiation damages cells by both intracellular and extracellular events. They are known as " $4 \mathrm{R}$ ” i.e., repair, re-oxygenation, redistribution and repopulation. None of these effects are cycling cell dependent. The events happen after the cells have been irradiated and the 4Rs conjointly sum up the final outcome of radiation on cancer cells. Irrespective of whether the cells are cycling or not. However, in cycling cells, phases G2 and M are relatively more radiosensitive; likely due to a higher number of target sites, prone to get damaged from ionizing radiation. As far as DNA strand break, that causes cellular radiation effects that are similar on individual DNA strands irrespective of the phase of the cell cycle [21].

\section{Effect of Tamoxifen on Radiation Effects on Cancer Cells}

As Tamoxifen increases percentage of G0/G1 phases, it will have a neutral impact on the cytotoxic effect of ionizing radiation. On the other hand, Tamoxifen also increases G2/M phases by blocking progress. It increases the number of apoptotic cells which are more radiosensitive than other phases likely due to the increased number of targets. Thus, the final outcome is a positive balance in favor of Tamoxifen concurrently administered with radiotherapy, which is likely to act as a radio-sensitizer [22].

\section{Concurrent or Sequential Adjuvant Therapy of Tamoxifen and Other Hormones with Radiotherapy (Table 2)}

Sequential or concurrent hormone therapy with radiotherapy for breast cancer is currently being debated. With the laboratory experimental clinical trials, the balance is in favor of concurrent usage of Tamoxifen with radiotherapy. It is important to get the best timing for hormonal adjuvant with radiation therapy, since hormones are

Table 2. Adjuvant concurrent vs sequential hormone therapy with radiotherapy: clinical studies and clinical study review.

\begin{tabular}{|c|c|c|}
\hline Author & Type of study & Conclusion \\
\hline Harris EE, et al. 2005 [24] & Retrospective 278 patients & $\begin{array}{l}\text { No clinical impact on cosmesis, complication either modality: } \\
\text { No comments on CON V SEQ }\end{array}$ \\
\hline Azria D, et al. 2005 [25] & Commentary (retrospective data) & “Concurrent” increases subcutaneous and pulmonary fibrosis \\
\hline Azria D, et al. 2004 [26] & Retrospective 147 patients & $\begin{array}{l}\text { "Concomitant”-Tamoxifen (Tam) increases sub-cut breast fibrosis } \\
\text { in hypersensitive patients }\end{array}$ \\
\hline Whelan T, et al. 2005 [27] & Editorial review & SEQ or CON: yet to be resolved Randomized trial recommended \\
\hline Pierce LJ, et al. 2005 [28] & Prospective randomized, 309 pts & $\begin{array}{l}\text { No difference in adverse effect, local or systemic recurrence } \\
\text { RT + TAM or RT only }\end{array}$ \\
\hline Ismail SS, et al. 2013 [29] & Prospective 160 patients & No difference RT + CON or SEQ \\
\hline Bentzen SM, et al. 1996 [30] & Retrospective 84 patients & Increase in lung fibrosis in CON Group \\
\hline Ishitobi M, et al. 2009 [31] & Retrospective 264 patients & No difference between CON and SEQ Group \\
\hline Tsoutsou PG, et al. 2010 [32] & Review & $\begin{array}{l}\text { May be given CON or SEQ (RT) Combination of Tamoxifen } \\
\text { and Letrozole recommended }\end{array}$ \\
\hline Ahn PH, et al. 2005 [33] & Retrospective 495 patients & $\begin{array}{l}\text { CON did not affect local control No observation on cosmesis } \\
\text { and toxicity }\end{array}$ \\
\hline Koc M, et al. 2002 [34] & Prospective 111 patients & $\begin{array}{l}\text { RT + TAM V RT + 0: Tele cobalt RT Significant risk of lung } \\
\text { fibrosis. No comment on CON V SEQ }\end{array}$ \\
\hline Cecchini MJ, et al. 2015 [35] & Literature review & SEQ supported due to increase in lung fibrosis in CON treatment \\
\hline Munshi A, et al. 2011 [36] & Randomized prospective & Results awaited (major study) \\
\hline
\end{tabular}


given for a period of 5 to 10 years. It is possible that minor but avoidable side effects from either choice might magnify to be a major clinical issue over a prolonged treatment period. Table 2 lists clinical and experimental findings to assist in developing a consensus of optimal use of hormones with radiotherapy for breast cancer patients.

\section{Effect of Surgery on Cancer Cell Kinetics}

Hippocratic physicians from the $5^{\text {th }}$ century BC through $7^{\text {th }}$ century AD believed that ulcerated breast lesions were likely to recur more aggressively if resected, than those which did not present with ulceration [23]. Even though the conventional wisdom had been not to operate on cancerous breast lesions to avoid faster recurrence and spread, with the advent of anesthesia, surgical techniques became wider and more extensive without any real benefit for either relapse or survival. Several clinical studies did indicate that post-surgical residual cancer and dormant cancer cells are activated following surgical excision, growing faster and metastasizing more widely with virulence (Table 3 ).

A wide range of experimental research indicated the rapid growth of lung metastasis following resection of leg sarcoma [3], increased vascularity and reduced apoptotic cells in post-colectomy hepatic metastasis in rats [14]. Surgical trauma's responsibility for post-mastectomy recurrence and spread was reiterated by mathematical models in animals [15]. There was also post-surgical spiking of the labeling index (LI) in experimental tumors [16], post-surgical increase in residual tumor size, progression to proliferative phase and synchronization to sensitive phases in experimental system [17] (Table 3, Table 4). Experimental studies also indicated the essential role of tumor stroma in carcinogenesis, prevention of neoplastic development and functional dedifferentiation of breast cancer cells into normal ductal growth [18] [19] (Table 4). As an important extra-cellular effect of Tamoxifen, irrespective of estrogen receptor status, Tamoxifen interacts with the stromal-fibroblasts of human breast cancer and induces production of TGF beta1 (TGF B family), which is a novel receptor-independent action of Tamoxifen. This function of Tamoxifen is a potent inhibitor for the epithelial cell cycle, hence progression and growth of breast cancer [53] [54].

Several clinical and clinicopathological studies indicated: cytoreductive surgery for testicular tumors, enhanced tumor progression [20], and post-surgical accelerated growth of metastasis in non-small cell lung cancer [22]. Improved survival and relapse following Laparoscopic cholecystectomy compared to open cholecystectomy

Table 3. Clinical, clinicopathological and experimental studies: surgery + concomitant versus Sequential use of hormone in treatment of cancer patient.

\begin{tabular}{|c|c|c|}
\hline Author & Type of study & Conclusion \\
\hline Demicheli R, et al. 1997 [37] & $\begin{array}{l}\text { Experimental } \\
\text { Mathematical Model }\end{array}$ & $\begin{array}{l}\text { Two peaks after resection. Surgical trauma, essential to manifest the } \\
\text { peaks of recurrences }\end{array}$ \\
\hline Peters CFJM, et al. 2006 [38] & $\begin{array}{l}\text { Experimental \& } \\
\text { Clinicopathological }\end{array}$ & $\begin{array}{l}\text { After partial liver resection, residual tumor shows aggressive and } \\
\text { faster recurrence }\end{array}$ \\
\hline Schatten WE, 1958 [39] & Experimental & $\begin{array}{l}\text { Rapid growth of large number of latent pulmonary metastasis after } \\
\text { removal of primary in leg }\end{array}$ \\
\hline Lange PH, et al. 1980 [40] & $\begin{array}{l}\text { Retrospective } \\
\text { Pathological \& Serological }\end{array}$ & $\begin{array}{l}\text { Tumor progressed after cytoreductive surgery: clinical trial urged. } \\
\text { Post resection recurrence of testicular tumors }\end{array}$ \\
\hline Demicheli R, et al. 2008 [41] & Review \& Critical Appraisal & $\begin{array}{l}\text { From tumor dormancy to surgery driven enhancement of growth and } \\
\text { metastasis likely }\end{array}$ \\
\hline Baum M, et al. 2005 [42] & Review \& Critical Appraisal & $\begin{array}{l}\text { Surgery induced angiogenesis and proliferation of distant dormant } \\
\text { micro-metastasis }\end{array}$ \\
\hline Lacy AM, et al. 2002 [43] & Randomized Prospective & $\begin{array}{l}\text { Laparoscopy assisted colectomy is superior than open colectomy; } \\
\text { Morbidity, hospital stay, recurrence and Ca-related death, less: due } \\
\text { to less surgical tissue damage }\end{array}$ \\
\hline Mitsudomi T, et al. 1996 [44] & Retrospective & $\begin{array}{l}\text { Post-surgical accelerated growth of undetectable residual cancer and } \\
\text { dormant cancer cells }\end{array}$ \\
\hline Gunduz N, et al. 1979 [45] & Retrospective & $\begin{array}{l}\text { Post-surgical increase in residual tumor size; conversion of G0 to } \\
\text { proliferative phase; synchronization of sensitive phases }\end{array}$ \\
\hline Fisher B, et al. 1983 [46] & Experimental & $\begin{array}{l}\text { Labelling Index (LI) peaks } 3 \text { days after tumor excision; Perioperative } \\
\text { chemotherapy recommended }\end{array}$ \\
\hline
\end{tabular}


Table 4. Biological changes in post-operative environment: clinical and experimental findings.

\begin{tabular}{|c|c|c|}
\hline Author & Type of study & Conclusion \\
\hline Maniwa Y, et al. 1998 [47] & Clinical \& Experimental & $\begin{array}{l}\text { Disruption of angiogenesis suppression, induction of growth } \\
\text { of dormant micro-metastasis due to post-op increase in VEGF }\end{array}$ \\
\hline Ikeda M, et al. 2002 [48] & Clinical & $\begin{array}{l}\text { Peri-gastrectomy serum concentration of VEGF, sP-selectin, v } \\
\text { WF, involved in angiogenesis, tumor-platelet adhesion, } \\
\text { tumor-endothelial cell adhesion factors; surgical intervention } \\
\text { enhanced tumor growth and metastasis }\end{array}$ \\
\hline Tagliabue E, et al. 2003 [49] & Clinical-operative specimen & $\begin{array}{l}\text { HER2 over-expression by breast ca cells plays in post-surgery } \\
\text { stimulation of growth of breast cancer cells }\end{array}$ \\
\hline Wu FP, et al. 2003 [50] & $\begin{array}{l}\text { Prospective Patho-physio, Cancer v } \\
\text { normal tissue, } 16 \text { specimens }\end{array}$ & $\begin{array}{l}\text { Local VEGF increase \& endostatin decrease; physiological } \\
\text { response to surgery, with or without cancer }\end{array}$ \\
\hline Mitsudomi T, et al. 1996 [44] & Retrospective Clinical (197 cases) & $\begin{array}{l}\text { Concluded residual tumor cells had accelerated growth after } \\
\text { surgery }\end{array}$ \\
\hline Maffani MV, et al. 2004 [51] & Experimental & $\begin{array}{l}\text { Important role of tumor stroma indicated; further extensive } \\
\text { study recommended }\end{array}$ \\
\hline Maffani MV, et al. 2005 [52] & Experimental & $\begin{array}{l}\text { Rat mammary gland tumor stroma prevents neoplastic } \\
\text { development and encourage normal ductal growth from } \\
\text { grafted epithelial cancer cells }\end{array}$ \\
\hline
\end{tabular}

suggests surgical trauma or lack of it is a responsible factor [24], as are disruptions of tumor-host homeostasis and activation of dormant cells [25], etc. Clinical and experimental studies indicated, post-operative increase in VEGF and a decrease in endostatin [27]. VEGF-induced angiogenesis stimulates growth of micro-metastasis [25] [26]. Post-gastrectomy increase in angiogenic factor, tumor-platelet adhesion factor, and tumor-endothelial cell adhesion factor influence tumor growth and metastasis [26] and post-surgical over-expression of HER2, stimulating cancer cell growth [35] (Table 4). Illustrated Figure 1 and Figure 2 indicates a possible existing dynamic tumor-host homeostasis (anticipate inherent changing balance by mutual consent) and results of disruption caused by surgical excision of the tumor, initiated by the "Substrate Vacuum" i.e., loss of the tumor mass, loss of stromal control on tumor growth and reduction of metastasis.

\section{Effect of Tamoxifen on Surgery Induced Changes in Cancer Cell Kinetics}

Having extensively reviewed clinical, clinic-pathological and experimental findings, the changes induced by Tamoxifen in post-operative surgical environment is getting clearer. The result of surgery alone in patients with cancer is essentially undesirable, except very small tumors which are yet to develop; a form of biological dynamic symbiosis between the tumor and host environment.

Strong evidences are now available to support the 2500-year-old Hippocratic dictum, not to operate on breast lesions which have ulcerated, because it regrows fast and spreads faster. We have enough striking evidence (Table 3, Table 4) to support the notion that postoperative loss of homeostatic balance between the tumor and the noncancerous elements, especially the stroma, induces residual cancer regrowth faster; micro-metastasis and dormant cancer cells are reactivated, changing to fast-proliferating, fast-metastasizing invasive cells. Surgical loss of stromal elements of the tumor, which commands significant influence on suppression of tumor proliferation, also negatively affects post-operative tumor control.

Hormones, i.e., Tamoxifen, which arrest cycling cells at G0 and G2 phases from progressing to G1 and M phases, respectively, are less likely to be affected by the post-operative perturbation of tumor-host homeostasis that induces accelerated tumor growth and metastasis. Thus perioperative use of Tamoxifen will prevent or reduce surgery induced accelerated residual tumor proliferation and metastasis. Also Non-hormonal control of Tamoxifen, tumor proliferation, with the help of tumor and normal stromal components, that aids retarding post-operative tumor recurrence and proliferation.

\section{Recommendation of Sequencing Hormones with Other Therapeutic Agents}

To rationalize sequencing Tamoxifen-like hormones, with other modalities, one needs to consider pharmacokinetics and pharmacodynamics of the hormone. Tamoxifen peaks at around 5 hours after a single oral use. To achieve a steady state plasma concentration, it takes 4 weeks, while on daily oral intake. The biphasic decline of 
Array of Gene and Growth Factor Expression in Breast Cancer with Tumor Host Homeostasis

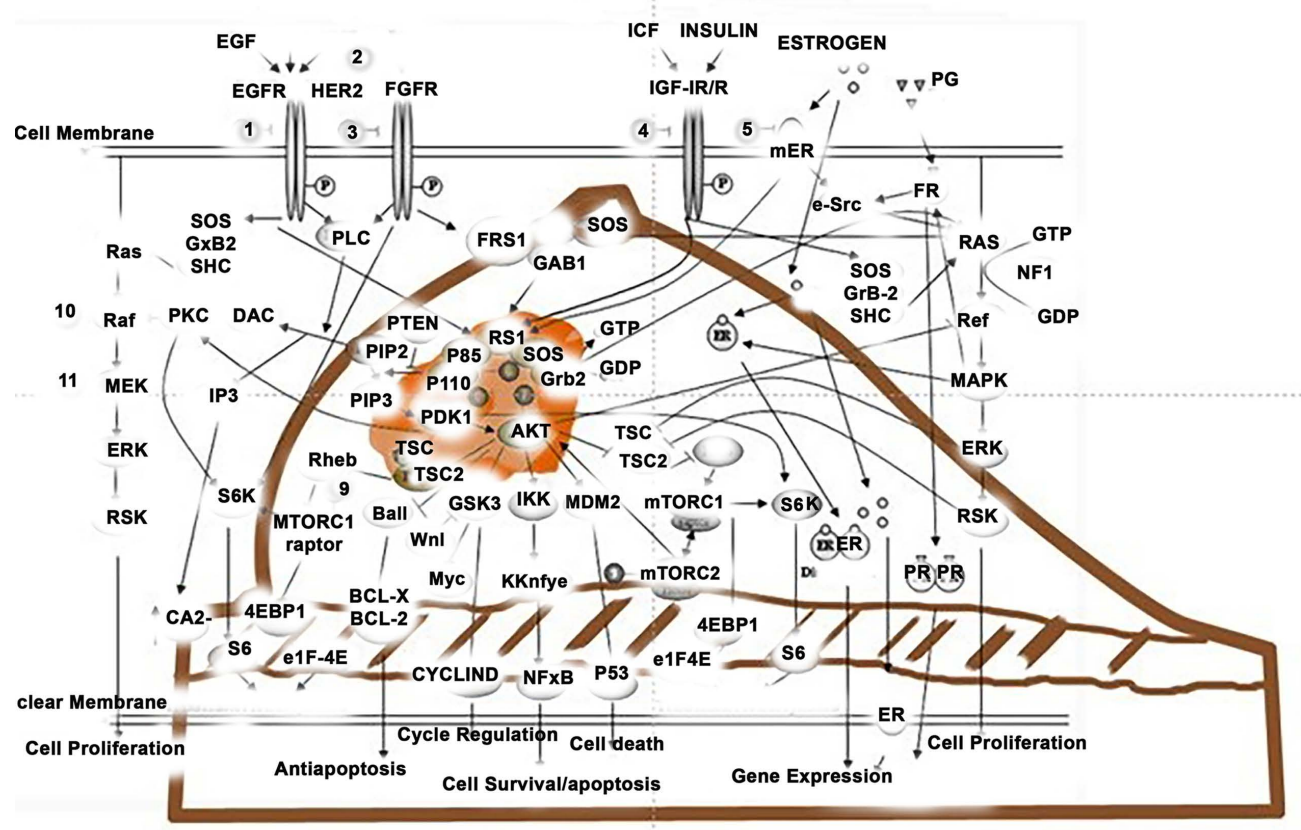

Tumor $=$ Substrate

Figure 1. Array of gene and growth factor expression in breast cancer with tumor host homeostasis.

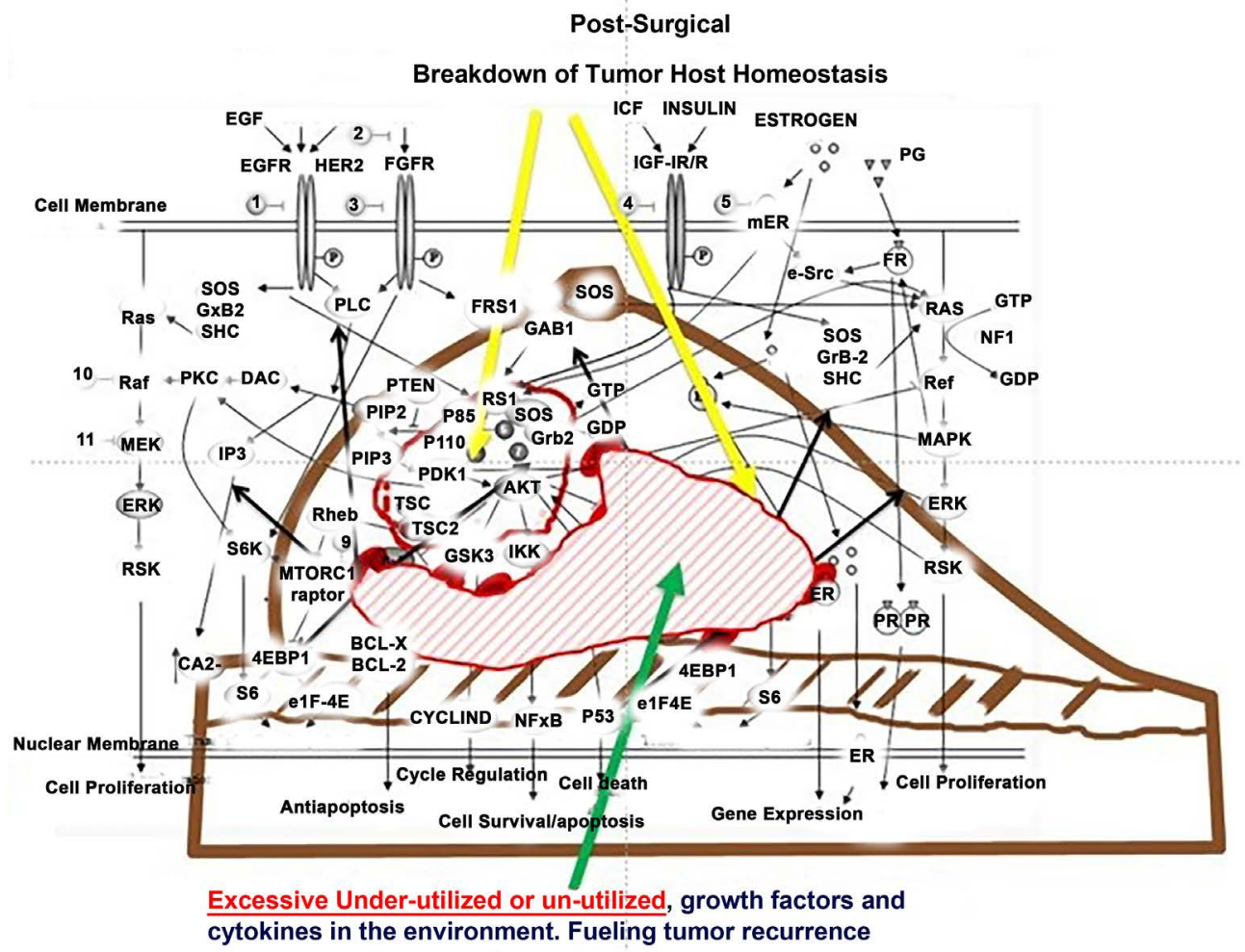

Figure 2. Post-surgical breakdown of tumor-host homeostasis and loss of stromal interaction. 
plasma concentration pattern accounts for its biological half-life of 5 - 7 days. Sixty-five percent is excreted through feces over 14 days [54] [55].

Hence one needs to be aware of the pharmacology and biological effect of hormones used as adjuvants to a multimodality treatment plan, as well as the effect of Tamoxifen on the kinetics of the tumor itself and its impact on an individual agent's biological action on growth and metabolic kinetics of the targeted tumor. Thus an essentially pharmacological approach will impact the aggregate effect of multi-modality agents on the final outcome of hormonal adjuvant.

\subsection{Tamoxifen and Chemotherapy}

Tamoxifen and, for that matter, other cytostatic anti-hormonal agents, it is apparent from the above overview, act against the cytotoxic effect of chemotherapy drugs and would compromise the therapeutic benefit of chemotherapy. Tamoxifen should be stopped at least 7 days before commencement of chemotherapy. It needs to be resumed soon after ( 1 - 3 days), depending on chemotherapy drug elimination rate, and as soon as the prescribed cycle is completed. Hence, Tamoxifen and other cytostatic anti-hormones should be used sequentially with chemotherapy and not concurrently.

\subsection{Tamoxifen and Radiotherapy}

From the above overview, it appears that the biological impact of Tamoxifen on radiotherapy has been protective (detrimental) against radiotherapy due to G0/G1 block; also, cells in G0/G1 phase are relatively resistant to DNA damage due to a higher ability to repair. On the other hand, Tamoxifen induced G2-M delay/block has a sensitizing effect on radiotherapy, likely due to a higher number of target sites. The composite effect of Tamoxifen and, for that matter, aromatase-inhibitors have moderate radio sensitizing benefit. Unfortunately, this advantage is counterbalanced by the excessive fibrosis of lung and breast tissue (perhaps other sites too) postconcurrent Tamoxifen-radiotherapy treatment for breast cancer. This is an important fact to note in developing countries where radiotherapy is given mostly in tele-cobalt units, which do induce higher post-radiation fibrosis as compared to treatment by Linear Accelerators. Concurrent use of Tamoxifen with tele-cobalt generated radiotherapy, without any doubt, will exacerbate fibrosis of lung, chest wall, and the preserved breast after limited resection. Some individuals are sensitive to radiation, if detected, they should also not be given Tamoxifen concurrently with radiotherapy. A simple Lymphocyte-sensitive test can reasonably detect radiosensitive individuals. Otherwise some physical features, i.e., people with blue eye, red hair, Irish-freckles, and people with tuberal sclerosis, xeroderma pigmentosa are known to be radiosensitive, should not be given tamoxifen concurrent with radiotherapy.

Thus, it is fair to use Tamoxifen sequentially with radiotherapy and not concurrently. Tamoxifen needs to be stopped 5 - 7 days (expected serum level to be lower than steady state, hence reduced bio-availability) prior to commencement of radiotherapy and resume couple of days after the last fraction of radiotherapy.

\subsection{Tamoxifen and Surgery}

From the above review, it is apparent that surgery does impact negatively on tumor control by accelerating proliferation of residuum and activating growth and metastasis of "dormant" microscopic non-proliferating tumor components. Tamoxifen and other cytostatic anti-hormone agents can inhibit to some extent this "blast" of postoperative tumor proliferative activities by retaining cells in the non-proliferative phase (G0/G1, G2-M). Hence, Tamoxifen and other cytostatic anti-hormones should be started 2 - 4 weeks prior to surgery and continued until there is a therapeutic reason to stop or pause.

Therefore, as soon as a tissue diagnosis confirms malignancy of the breast, even before the receptor results are available, it is recommended that Tamoxifen or Letrozole in post-menopausal patients be started to control tumor growth. It can be stopped if the receptors are reported to be negative, as and if they are available. The non-hormonal extra-cellular activity of Tamoxifen and Tamoxifen-stromal interactive-influence on suppression of cellular proliferation will also have a positive impact.

\section{Limited Resource Countries-Optimizing Adjuvant Tamoxifen (Other Such Hormones Used for Adjuvant Treatment for Breast Cancer)}

In developing countries, where resources are scarce and there is delay in getting the desirable surgery, a delay in 
obtaining chemotherapy agents, a delay or non-availability of radiotherapy or even unavailability of "receptor status"; it is prudent to start Tamoxifen for all premenopausal and Letrozole to postmenopausal patients with biopsy proven breast cancer, prior to any definitive therapy, unless there is a preexisting clinical condition that dictates otherwise. Tamoxifen is inexpensive and generally available even in the developing world. Its side effects are minimal and can be monitored by a general practitioner and periodically by Gynecologists, not necessarily a Gynecological-Oncologist.

In receptor "unavailable" cases, the tumor being "receptor positive" is around $75 \%$ in pre-menopausal and higher in post-menopausal cases [56]. The extra-hormonal, extracellular, anti-breast cancer activity of Tamoxifen should also be taken into account. This essentially ignored function of Tamoxifen does add to the anti-cancer activity, irrespective of "receptor status". The advantages of adding Tamoxifen to the armamentarium of breast cancer treatment far outweigh the disadvantages and risks in receptor "unavailable" cases [57] [58]. Tamoxifen does reduce recurrences in the affected breast and also in the contralateral breast with DCIS, following lumpectomy and radiation; irrespective of receptor status [59].

Specifically, it is worth reiterating that the majority of developing countries' radiotherapy is delivered by tele-cobalt treatment unit. Extra effort should be made to ensure that Tamoxifen is stopped 1 - 2 weeks prior to starting radiotherapy and resumes 2 days after the last fraction, to minimize soft tissue post-radiation fibrosis (by this period, serum levels would have been reduced to an acceptable steady state, appropriate for the need).

As far as sequencing of Tamoxifen and like agents (Letrozole) for chemotherapy and surgery is concerned, evidence suggests the sequencing may be carried out as per resource rich countries, recommended in this overview.

While the developing world pines for acquisition of high tech, high cost, complex technology, and expertise-dependent interventions, that remains a wishful desire. These may be common in the developed world, but are unlikely to be available in limited resource countries. At the same time, LRC miss the simple adjustment to practice that may impact them profoundly; appreciation of a simple management strategy like "Optimizing Tamoxifen Sequencing" for breast cancer, as well as other neglected biological phenomena like "utilization of diurnal variation of drug effectiveness" and simpler technology utilizing "hyperthermia" to enhance the oncotoxic effect of other modalities, the scope of inhalation chemotherapy, etc. There are many other examples whose aggregate effect may supersede the therapeutic impact of most modern complex technological advances for cancer management.

\section{Conclusions (Figure 3 for Graphic Recommendation)}

It is a standard practice to prescribe Tamoxifen for hormone receptor positive patients with breast cancer. Immunohistochemical assay for hormone receptor of breast cancer is expensive and beyond reach for most "resource limited" regions, where eighty percent of world's population lives. However, the benefit of using Tamoxifen as an adjuvant treatment for "receptor unknown" cases of breast cancer far outweighs the dangers of recurrence and spread. Tamoxifen is far more readily available in resource limited country than the availability of immunohistochemical test. Hence, it is advised that irrespective of the "receptor status" all women with breast cancer can be placed on Tamoxifen or like, as long as there are no preexisting risk factors like, history of coagulopathy, DVT, diabetes, extensive varicosity etc.

It is suggested that as soon as histopathological diagnosis of primary breast cancer is confirmed, patients should be started on Tamoxifen (Letrozole for postmenopausal). Then, the plan should be amended when or if the receptor status becomes available.

Patients should continue Tamoxifen throughout the course of planned surgical management.

If radiotherapy is planned, Tamoxifen should be stopped 7 days prior to starting radiotherapy. If the patient is found to be radiosensitive on a Lymphocyte sensitivity test (a simple, but very useful test) or the patient has physical features of radio sensitivity i.e., blue eyes, red hair, skin with excessive freckles; then there should be restrictions. Even mixed races with above features would have these restrictions. If suspended, then Tamoxifen should be started on the last day of radiotherapy. Otherwise Tamoxifen should be continued throughout the course of radiotherapy.

If chemotherapy is planned; Tamoxifen should be stopped 7 days prior to starting of chemotherapy and resume 2 days after the last infusion of chemotherapy. By that time, the effective role of chemotherapy would have waned.

Patients who are placed on Tamoxifen should be regularly checked by both an oncologist and gynecologist. 


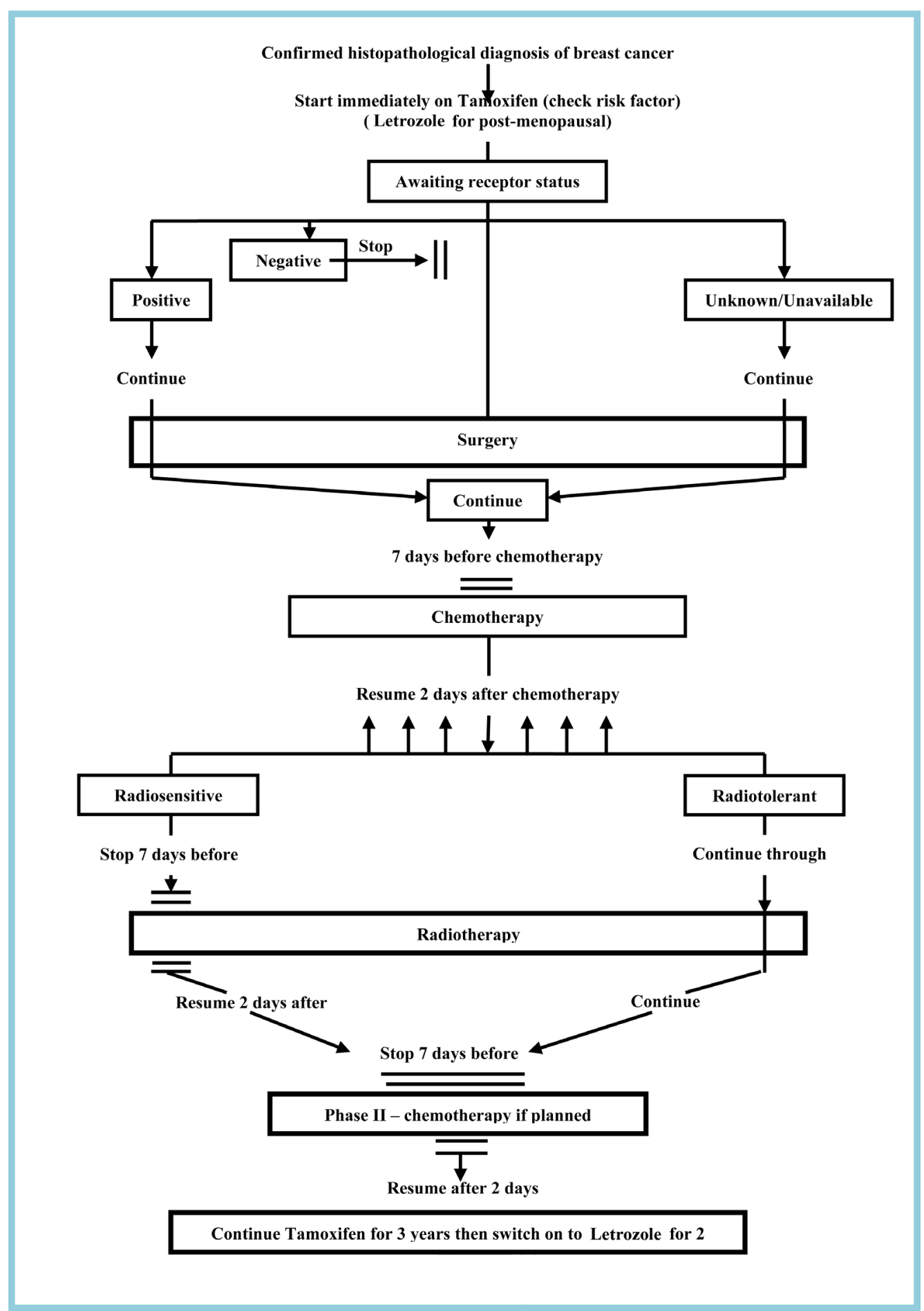

Figure 3. Comprehensive schema of Tamoxifen (Letrozole) during multimodality therapy and follow-up.

\section{Acknowledgements}

To Prof Dr Gerald Grell, friend \& critique, Dr Ruby Blanc, Medical director of Princess Margaret Hospital; all my patients at the clinic who questioned about the hormones, my physician colleagues, the nursing staff including Sister Sharon Darroux Francis, Nurse Clara Richards and Nurse Aisha Darroux who are ever vigilant on timing of Tamoxifen and Amina Toussaint for secretarial assistance. 


\section{References}

[1] Recht, A., Come, S.E., Gellman, R.S., Goldstein, M., Tishler, S., Gore, S.M., Abner, A.L., Vicini, F.A., Silver, B. and Connolly, J.L. (1991) Integration of Conservative Surgery, Radiotherapy, and Chemotherapy for the Treatment of Early-Stage, Node-Positive Breast Cancer: Sequencing, Timing, and Outcome. Journal of Clinical Oncology, 9, 16621667.

[2] Gradishar, W. (2006) Landmark Trials in Endocrine Adjuvant Therapy for Breast Carcinoma. Cancer, 106, $975-981$. http://dx.doi.org/10.1002/cncr.21707

[3] Baum, M., et al. (1988) Controlled Trial of Tamoxifen as a Single Adjuvant Agent in the Management of Early Breast Cancer. 'Nolvadex’ Adjuvant Trial Organization. British Journal of Cancer, 57, 608-611. http://dx.doi.org/10.1038/bjc.1988.138

[4] Osborne, C.K., Boldt, D.H., Clark, G.M. and Trent, J.M. (1983) Effects of Tamoxifen on Human Breast Cancer Cell Cycle Kinetics: Accumulation of Cells in Early G1 Phase. Cancer Research, 43, 3583-3585.

[5] Sutherland, R.L., Green, M.D., Hall, R.E., Reddel, R.R. and Taylor, I.W. (1983) Tamoxifen Induces Accumulation of MCF 7 Human Mammary Carcinoma Cells in the G0/G1 Phase of the Cell Cycle. European Journal of Cancer and Clinical Oncology, 19, 615-621. http://dx.doi.org/10.1016/0277-5379(83)90177-3

[6] Malaker, K., Gillies, J.M. and Meikle, A. (1981) Cytostatic Effect of Tamoxifen Causing G0/G1 Delay in Cycling Breast Cancer Cells, May Adversely Affect Therapeutic Benefit of Chemotherapy Agents. Manitoba Cancer Treatment Research Foundation (MCTRF) Annual Report, Radiation Oncology Section, Winnipeg, 201.

[7] Doisneau-Sixou, S.F., Sergio, C.M., Carroll, J.S., Hui, R., Musgrove, E.A. and Sutherland, R.L. (2003) Estrogen and Antiestrogen Regulation of Cell Cycle Progression in Breast Cancer Cells. Endocrine Related Cancer, 10, 179-186. http://dx.doi.org/10.1677/erc.0.0100179

[8] Lippman, M.E. and Dickson, R.B. (2012) Regulatory Mechanisms in Breast Cancer. Advances in Cellular and Molecular Biology of Breast Cancer, 306-322.

[9] Patterson, J., Furr, B., Wakeling, A. and Battersby, L. (1982) The Biology and Physiology of 'Nolvadex' (Tamoxifen) in Treatment of Breast Cancer. Breast Cancer Research and Treatment, 2, 363-374. http://dx.doi.org/10.1007/BF01805878

[10] Lykkesfeldt, A.E., Larsen, J.K., Christensen, I.J. and Briand, P. (1984) Effects of the Antioestrogen Tamoxifen on the Cell Cycle Kinetics of the Human Breast Cancer Cell Line, MCF-7. British Journal of Cancer, 49, 717-722. http://dx.doi.org/10.1038/bjc.1984.113

[11] St. Croix, B., Florenes, V.A., Rak, J.W., Flanagan, M., Bhattacharya, N., Slingerland, J.M. and Kerbel, R.S. (1996) Impact of the Cyclin-Dependent Kinase Inhibitor p27Kip1 on Resistance of Tumor Cells to Anticancer Agents. Nature Medicine, 2, 1204-1210. http://dx.doi.org/10.1038/nm1196-1204

[12] Hall, E.J. and Giaccia, A.J. (2012) Radiobiology for the Radiologist. 7th Edition, Lippincott Williams \& Wilkins. Chemotherapeutic Agents from Perspective of Radiation Biologist, 449-475.

[13] Lippman, M.E., Cassidy, J., Wesley, M. and Young, R.C. (1984) A Randomized Attempt to Increase the Efficacy of Cytotoxic Chemotherapy in Metastatic Breast Cancer by Hormonal Synchronization. Journal of Clinical Oncology, 2, 28-36.

[14] Pritchard, K.I. (2008) Combining Endocrine Agents with Chemotherapy: Which Patients and What Sequence? Cancer, 112, 718-722. http://dx.doi.org/10.1002/cncr.23189

[15] Albain, K., Green, S. and Ravdin, P. (2002) Adjuvant Chemotherapy with Hormone Therapy for Primary Breast Cancer Should Be Sequential Instead of Concomitant: Initial Results from Intergroup Trial 0100 (SWOG-8814). Proceedings of American Society of Clinical Oncology, 21-37a.

[16] Pico, C., Martin, M., Jara, C., Barnadas, A., Pelegri, A., Balil, A., Camps, C., Frau, A., Rodriquez-Lescure, A., LopezVega, J.M., De La Haba, J., Tres, A., Alvarez, I., Alba, E., Arcusa, A., Oltra, A., Batista, N., Checa, T., Perez-Carrion, R. and Curto, J., GEICAM Group (2004) Epirubicin-Cyclophosphamide Adjuvant Chemotherapy plus Tamoxifen Administered Concurrently versus Sequentially: Randomized Phase III Trial in Postmenopausal Node-Positive Breast Cancer Patients. A GEICAM 9401 Study. Annals of Oncology, 15, 79-87. http://dx.doi.org/10.1093/annonc/mdh016

[17] Bedognetti, D., Sertoli, M.R., Pronzato, P., Del Mastro, L., Venturini, M., Taveggia, P., Zanardi, E., Siffredi, G., Pastorino, S., Queirolo, P., Gardin, G., Wang, E., Monzeglio, C., Boccardo, F. and Bruzzi, P. (2011) Concurrent versus Sequential Adjuvant Chemotherapy and Hormone Therapy in Breast Cancer: A Multicenter Randomized Phase III Trial. Journal of the National Cancer Institute, 103, 1529-1539. http://dx.doi.org/10.1093/jnci/djr351

[18] Del Mastro, L., Dozin, B., Aitini, E., Catzeddu, T., Baldini, E., Contu, A., Durando, A., Danese, S., Cavazzini, G., Canavese, G., Bruzzi, P., Pronzato, P. and Venturini, M., GONO-MIG Group (2008) Timing of Adjuvant Chemotherapy and Tamoxifen in Women with Breast Cancer: Findings from Two Consecutive Trials of Gruppo Oncologico NordOvest-Mammella Intergruppo (GONO-MIG) Group. Annals of Oncology, 19, 299-307. 
http://dx.doi.org/10.1093/annonc/mdm475

[19] Sideras, K. (2010) Tamoxifen Timing in Postmenopausal Breast Cancer Patients. NAMS. http://www.medscape.com/viewarticle/717750

[20] Early Breast Cancer Trialists’ Collaborative Group (EBCTCG) (2005) Effects of Chemotherapy and Hormone Therapy for Early Breast Cancer on Recurrence and 15-Year Survival: An Overview of the Randomized Trials. The Lancet, 365, 1687-1717. http://dx.doi.org/10.1016/S0140-6736(05)66544-0

[21] Hall, E.J. and Giaccia, A.J. (2012) Radiobiology for the Radiologist. Chapter 5. Fractionated Radiation and Dose-Rate Effect. 7th Edition, Lippincott Williams \& Wilkins, Philadelphia, 67-101.

[22] Yang, L., Yuan, X., Wang, J., Gu, C., Zhang, H., Yu, J. and Liu, F. (2015) Radiosensitization of Human Glioma Cells by Tamoxifen is Associated with the Inhibition of PKC-I Activity in Vitro. Oncology Letters, 10, 473-478.

[23] Papavramidou, N., Papavramidis, T. and Demetriou, T. (2010) Ancient Greek and Greco-Roman Methods in Modern Surgical Treatment of Cancer. Annals of Surgical Oncology, 17, 665-667. http://dx.doi.org/10.1245/s10434-009-0886-6

[24] Harris, E.E., Christensen, V.J., Hwang, W.T., Fox, K. and Solin, L. (2005) Impact of Concurrent versus Sequential Tamoxifen with Radiation Therapy in Early-Stage Breast Cancer Patients Undergoing Breast Conservation Treatment. Journal of Clinical Oncology, 23, 11-16. http://dx.doi.org/10.1200/JCO.2005.09.056

[25] Azria, D., Pelegrin, A., Dubois, J.B., Mirimanoff, R.O. and Ozsahin, M. (2005) Radiation Therapy and Tamoxifen: Concurrent or Sequential? It's No Longer the Question! Journal of Clinical Oncology, 23, 4239-4241. http://dx.doi.org/10.1200/JCO.2004.00.8623

[26] Azria, D., Gourgou, S., Sozzi, W.J., Zouhair, A., Mirimanoff, R.O., Kramar, A., Lemanski, C., Dubois, J.B., Romieu, G., Pelegrin, A. and Ozsahin, M. (2004) Concomitant Use of Tamoxifen with Radiotherapy Enhances Subcutaneous Breast Fibrosis in Hypersensitive Patients. British Journal of Cancer, 91, 1251-1260. http://dx.doi.org/10.1038/sj.bjc.6602146

[27] Whelan, T. and Levine, M. (2005) Radiation Therapy and Tamoxifen: Concurrent or Sequential? That Is the Question. Journal of Clinical Oncology, 23, 1-4. http://dx.doi.org/10.1200/JCO.2005.08.955

[28] Pierce, L.J., Hutchins, L.F., Green, S.R., Lew, D.L., Gralow, J.R., Livingston, R.B., Osborne, C.K. and Albain, K.S. (2005) Sequencing of Tamoxifen and Radiotherapy after Breast-Conserving Surgery in Early-Stage Breast Cancer. Journal of Clinical Oncology, 23, 24-29. http://dx.doi.org/10.1200/JCO.2005.01.198

[29] Ismail, S.S., Abdel-Hafeez, Z.M., EL Khodary, D.A.E. and Kelany, M.R. (2013) Trial of Concurrent versus Sequential Tamoxifen with Radiotherapy in Breast Cancer Patients with Study of the Combination of Pentoxifylline and Tocopherol for Prevention of Radiation-Induced Lung Fibrosis. Journal of Clinical Oncology, 31, e11599.

[30] Bentzen, S.M., Skoczylas, J.Z., Overgaard, M. and Overgaard, J. (1996) Radiotherapy-Related Lung Fibrosis Enhanced by Tamoxifen. Journal of the National Cancer Institute, 88, 918-922. http://dx.doi.org/10.1093/jnci/88.13.918

[31] Ishitobi, M., Komoike, Y., Motomura, K., Koyama, H., Nishiyama, K. and Inaji, H. (2009) Retrospective Analysis of Concurrent vs. Sequential Administration of Radiotherapy and Hormone Therapy Using Aromatase Inhibitor for Hormone Receptor-Positive Postmenopausal Breast Cancer. Anticancer Research, 29, 4791-4794.

[32] Tsoutsou, P.G., Belkacemi, Y., Gligorov, J., Kuten, A., Boussen, H., Bese, N., Koukourakis, M.I. and on Behalf of Association of Radiotherapy and Oncology in the Mediterranean Area (2010) Optimal Sequence of Implied Modalities in the Adjuvant Setting of Breast Cancer Treatment: An Update on Issues to Consider. The Oncologist, 15, 1169-1178. http://dx.doi.org/10.1634/theoncologist.2010-0187

[33] Ahn, P.H., Vu, H.T., Lannin, D., Obedian, E., DiGiovanna, M.P., Burtness, B. and Haffty, B.G. (2005) Sequence of Radiotherapy with Tamoxifen in Conservatively Managed Breast Cancer Does Not Affect Local Relapse Rates. Journal of Clinical Oncology, 23, 17-23. http://dx.doi.org/10.1200/JCO.2005.09.048

[34] Koc, M., Polat, P. and Suma, S. (2002) Effect of Tamoxifen on Pulmonary Fibrosis after Cobalt-60 Radiotherapy in Breast Cancer Patients. Radiotherapy and Oncology, 64, 171-175. http://dx.doi.org/10.1016/S0167-8140(02)00136-6

[35] Cecchini, M.J., Yu, E., Potvin, K., D’souza, D. and Lock, M. (2015) Concurrent and Sequential Hormonal and Radiation Therapy in Breast Cancer: A Literature Review. Cureus, 7, e364. http://dx.doi.org/10.7759/cureus.364

[36] Munshi, A. and Gupta, D. (2011) Concurrent versus Sequential Radiotherapy and Tamoxifen in Breast Cancer-The CONSET Trial Is Launched. Acta Oncologica, 50, 154-155. http://dx.doi.org/10.3109/0284186X.2010.504228

[37] Demicheli, R., Retsky, M.W., Swartzendruber, D.E. and Bonadonna, G. (1997) Proposal for a New Model of Breast Cancer Metastatic Development. Annals of Oncology, 8, 1075-1080. http://dx.doi.org/10.1023/A:1008263116022

[38] Peeters, C.F.J.M., de Waal, R.M., Wobbes, T., Westphal, J.R. and Ruers, T.J. (2006) Outgrowth of Human Liver Metastases after Resection of the Primary Colorectal Tumor: A Shift in the Balance between Apoptosis and Proliferation. International Journal of Cancer, 119, 1249-1253. http://dx.doi.org/10.1002/ijc.21928 
[39] Schatten, W.E. (1958) An Experimental Study of Postoperative Tumor Metastases. I. Growth of Pulmonary Metastases following Total Removal of Primary Leg Tumor. Cancer, 11, 455-459. http://dx.doi.org/10.1002/1097-0142(195805/06)11:3<455::AID-CNCR2820110303>3.0.CO;2-3

[40] Lange, P.H., Hekmat, K., Bosl, G., Kennedy, B.J. and Fraley, E. (1980) Accelerated Growth of Testicular Cancer after Cytoreductive Surgery. Cancer, 45, 1498-1506. http://dx.doi.org/10.1002/1097-0142(19800315)45:6<1498::AID-CNCR2820450633>3.0.CO;2-7

[41] Demicheli, R., Retsky, M.W., Hrushesky, W., Baum, M. and Gukas, I.D. (2008) The Effects of Surgery on Tumor Growth: A Century of Investigations. Annals of Oncology, 19, 1821-1828. http://dx.doi.org/10.1093/annonc/mdn386

[42] Baum, M., Demicheli, R., Hrushesky, W. and Retsky, M. (2005) Does Surgery Unfavorably Perturb the "Natural History" of Early Breast Cancer by Accelerating the Appearance of Distant Metastases? European Journal of Cancer, 41, 508-515. http://dx.doi.org/10.1016/j.ejca.2004.09.031

[43] Lacy, A.M., Garcia-Valdecasas, J.C., Delgado, S., Castells, A., Taurá, P., Piquè, J.M. and Visa, J. (2002) LaparoscopyAssisted Colectomy versus Open Colectomy for Treatment of Non-Metastatic Colon Cancer: A Randomized Trial. The Lancet, 359, 2224-2229. http://dx.doi.org/10.1016/S0140-6736(02)09290-5

[44] Mitsudomi, T., Nishioksa, K., Maruyama, R., Saitoh, G., Hamat ake, M., Fukuyama, Y., Yaita, H., Ishida, T. and Sugimachi, K. (1996) Kinetic Analysis of Recurrence and Survival after Potentially Curative Resection of Nonsmall Cell Lung Cancer. Journal of Surgical Oncology, 63, 159-165.

http://dx.doi.org/10.1002/(SICI)1096-9098(199611)63:3<159::AID-JSO5>3.0.CO;2-C

[45] Gunduz, N., Fisher, B. and Saffer, E.A. (1979) Effect of Surgical Removal on the Growth and Kinetics of Residual Tumor. Cancer Research, 39, 3861-3865.

[46] Fisher, B., Gunduz, N. and Saffer, E.A. (1983) Influence of the Interval between Primary Tumor Removal and Chemotherapy on Kinetics and Growth of Metastases. Cancer Research, 43, 1488-1492.

[47] Maniwa, Y., Okada, M., Ishii, N. and Kyiooka, K. (1998) Vascular Endothelial Growth Factor Increased by Pulmonary Surgery Accelerates the Growth of Micrometastases in Metastatic Lung Cancer. Chest, 114, 1668-1675.

http://dx.doi.org/10.1378/chest.114.6.1668

[48] Ikeda, M., Furukawa, H., Imamura, H., Shimizu, J., Ishida, H., Masutani, S., Tatsuta, M., Kawasaki, T. and Satomi, T. (2002) Surgery for Gastric Cancer Increases Plasma Levels of Vascular Endothelial Growth Factor and von Willebrand Factor. Gastric Cancer, 5, 137-141. http://dx.doi.org/10.1007/s101200200024

[49] Tagliabue, E., Agresti, R., Carcangiu, M.L., Ghirelli, C., Morelli, D., Campiglio, M., Martel, M., Giovanazzi, R., Greco, M., Balsari, A. and Ménard, S. (2003) Role of HER2 in Wound-Induced Breast Carcinoma Proliferation. The Lancet, 362, 527-533. http://dx.doi.org/10.1016/S0140-6736(03)14112-8

[50] Wu, F.P., Hoekman, K., Meijer, S. and Cuesta, M.A. (2003) VEGF and Endostatin Levels in Wound Fluid and Plasma after Breast Surgery. Angiogenesis, 6, 255-257. http://dx.doi.org/10.1023/B:AGEN.0000029410.32264.b0

[51] Maffini, M.V., Soto, A.M., Calabro, J.M., Ucci, A.A. and Sonnenschien, C. (2004) The Stroma as a Crucial Target in Rat Mammary Gland Carcinogenesis. Journal of Cell Science, 117, 1495-1502. http://dx.doi.org/10.1242/jcs.01000

[52] Maffini, M.V., Calabro, J.M., Soto, A.M. and Sonnenschien, C. (2005) Stromal Regulation of Neoplastic Development. Age-Dependent Normalization of Neoplastic Mammary Cells by Mammary Stroma. The American Journal of Patholology, 167, 1405-1410. http://dx.doi.org/10.1016/S0002-9440(10)61227-8

[53] Butta, A., MacLennan, K., Flanders, K.C., Sacks, N.P., Smith, I., McKinna, A., Dowsett, M., Wakefield, L.M., Sporn, M.B., Baum, M. and Colletta, A. (1992) Induction of Transforming Growth Factor Beta 1 in Human Breast Cancer in Vivo Following Tamoxifen Treatment. Cancer Research, 52, 4261-4264.

[54] Robinson, S.P., Langan-Fahey, S.M., Johnson, D.A. and Jordan, V.C. (1991) Metabolites, Pharmacodynamics and Pharmacokinetics of Tamoxifen in Rats and Mice Compared to Breast Cancer Patient. Drug Metabolism Disposition: Biological Fate of Chemicals, 19, 36-43.

[55] RxList (2008) Nolvadex. Clinical Pharmacology. http://www.rxlist.com/nolvadex-drug/clinical-pharmacology.htm

[56] National Cancer Institute (2014) Targeted Cancer Therapies. http://www.cancer.gov/about-cancer/treatment/types/targeted-therapies/targeted-therapies-fact-sheet

[57] Eniu, A., Carlson, R.W., Aziz, Z., Bines, J., Hortobágyi, G.N., Bese, N.S., Love, R.R., Vikram, B., Kurkure, A., Anderson, B.O. and for the Global Summit Treatment and Allocation of Resources Panel (2006) Breast Cancer in Limited-Resource Countries: Treatment and Allocation of Resources. The Breast Journal, 12, S38-S53. http://dx.doi.org/10.1111/j.1075-122X.2006.00202.x

[58] BMJ Best Practice (2015) Primary Invasive Breast Cancer Treatment-Step-By-Step. http://bestpractice.bmj.com/best-practice/monograph/716/treatment/step-by-step.html 
[59] Wapnir, I.L., Dignam, J.J., Fisher, B., Mamounas, E.P., Anderson, S.J., Julian, T.B., Land, S.R., Margolese, R.G., Swain, S.M., Costantino, J.P. and Wolmark, N. (2011) Long-Term Outcomes of Invasive Ipsilateral Breast Tumor Recurrences after Lumpectomy in NSABP B-17 and B-24 Randomized Clinical Trials for DCIS. Journal of the National Cancer Institute, 103, 478-488. http://dx.doi.org/10.1093/jnci/djr027

\section{Submit or recommend next manuscript to SCIRP and we will provide best service for you:}

Accepting pre-submission inquiries through Email, Facebook, Linkedin, Twitter, etc A wide selection of journals (inclusive of 9 subjects, more than 200 journals)

Providing a 24-hour high-quality service

User-friendly online submission system

Fair and swift peer-review system

Efficient typesetting and proofreading procedure

Display of the result of downloads and visits, as well as the number of cited articles

Maximum dissemination of your research work

Submit your manuscript at: http://papersubmission.scirp.org/ 